\title{
SYSTEM DYNAMICS FOR SIMULATION MODEL OF MATERIAL COST IN WATER RECOURCES PROJECT
}

\author{
I Wayan Mundra ${ }^{1}$, Hirijanto ${ }^{2 *}$ \\ ${ }^{1,2}$ Civil Engineering, National Institute of Technology (ITN) Malang, Indonesia
}

*Corresponding Email: hirijanto22@gmail.com

\begin{abstract}
Project cost is one of the constraints in the achievement of a construction project. Limitation on projects financing require more realistic and efficient cost analysis in preparation of project. Due to changes in projects planning over time, it is usually difficult to predict the future project cost. So, we need an integrated system and give an efficiency for the planner. Project cost consists of cost components which is there are an interrelationship each other's and influencing the overall cost of the project. The approach using system dynamic is one of the best solutions to identify the causal relationship between cost components by using software tools Ventana Simulation (Vensim) to facilitate the identification of causal relationship (causatic diagram) and mathematical equations between variables in stock flow diagram. The results of system dynamic approach show that the simulation model can be used to predict/ estimate the project's cost in the coming years. Verification and validation of simulation model is eligible based on the value of means comparison, $\mathrm{E}_{1}=0.32 \%<5 \%$ and \% error variance, $\mathrm{E}_{2}=3.19 \%<30 \%$ so the developed model can be done scenarios for changes that occur on the system according to the user needs.
\end{abstract}

Keywords: Project cost, Construction material, System dynamic

\section{Introduction}

The construction project is a unique activity because it involves components of various science fields and has limited cost, time and performance that has been set at the beginning of starting projects. The dynamic nature of construction project make it difference with another job field. The successful of construction project is if in the implementation achieved a balance between the three components (cost, time and performance).

Projects cost as one of the most commonly constrained items is an important component in the planning of construction works. Project finance is structured in a budget analysis of the project cost planning that accommodates all financial needs based on work breakdown analysis of project. Changing prices often occur during planning and execution of work filed so that a problem for implementation of construction work because it leads to losses and cost overrun.

Research conducted by Akantoye [1] and Toh [2] had already discussed factors related to projects costs on a general analysis so that the result obtained lead to the level of managerial decisions of construction project. Meanwhile, a study conducted by Betlejewska [3] discusses the comparison of cost saving ratio of traditional cost estimation system and energy efficiency in cost estimation [3]. Cheng [4] also studied factors affecting costs in a wide scope of environmental factor, constructions contract, project risk and management.

Prediction analysis can do by adopting several methods from other fields of science that can be applied in construction area as well as proven to facilitate various construction works including water resources projects. One of the application models that can be applied in prediction is using neural network methods based on database and works in accordance with the pattern recognition from our data [5]. Analysis of fuzzy hybrid neural network approach has also been studied in terms of estimation and prediction of construction project financing [6].

Generally, some studies in previous research are still static in a certain period of time, so if there is a possibility of the dynamically changing in the financing of construction project, then the method becomes less precise. So, we need an analysis using system dynamic to predict the price changes in project financing.

The previous research had already studied the unit price analysis of construction project based on information system so the existing data can be saved in a database server for next changing related to the policy taken. Basic analysis of this research is used to understand the behaviour of financing system of construction project so that it can be rearranged with system dynamic approach [7]. Web based assessment of cost estimation is also carried out by Cheng (2009) by conferring the 
relationship between activities in execution phase [8].

Contingency cost as a part of the project's indirect costs, for determination are usually done by traditional methods at about $5-10 \%$, but with a fuzzy expert system approach, the accuracy of approximately $20 \%$ give assurance of the estimated cost of construction projects [9].Partial analysis related to the prediction of unit price of construction workers reward is an initial study related to financing of construction projects with case study also in water resources field [10].

Based on the previous studies, its need a method for predicting changes in project costs through changes in unit price of work so that before the budget planning process of the project cost, there is an estimated value of the unit price used as a reference for planning and decision making. Due to the dynamic nature of the project with the interrelationship of cost components, the problem solving with system dynamic approach is appropriate.

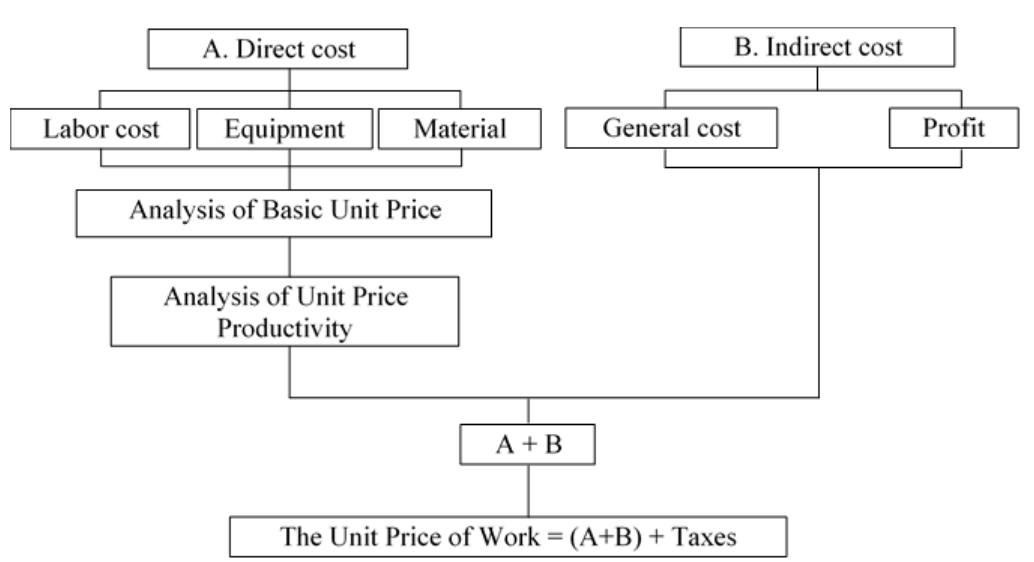

Figure 1 The Unit Price Structure in Construction Projects

The basic unit price of construction material is the amount of expenses incurred for procurement the material components to produce one unit of measurement of a particular job. Factors affecting the price in the basic unit of materials consists of material specification, quantity of material, distance of material warehouse and location of warehouse. Three components in the basic unit price is HSD quarry, HSD processed materials and HSD finished material (Figure 2) [11]. A quarry is a material from a particular location or source and the material has not processed/ original material (ex: stone, sand, etc) or material that

\section{Literature Review}

\subsection{The Unit Price Analysis of Construction Project}

The break down analysis of the unit price of construction projects consist of labor cost, material cost and the cost of equipment that used for projects completion. Based on figure 1, the unit price refers to the required analysis of cost in project activities which divided into direct cost and indirect cost. From indirect cost, it can be translated into labor components, building materials and equipment which directly influences the projects achievement. The direct cost produces the basic material unit price, the basic reward of labor unit price and the basic unit price of equipment. The basic unit price is the price of component of the currency of payment for a specific unit, for example $\mathrm{m}, \mathrm{m}^{2}, \mathrm{~m}^{3}$ for construction material. 


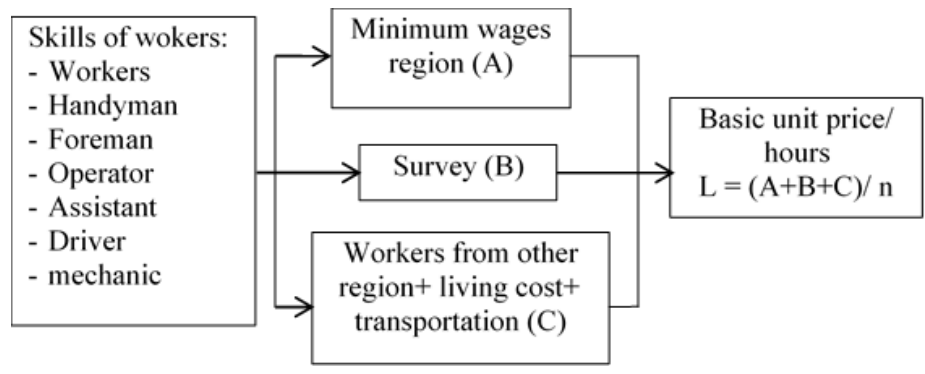

Figure 2 The Basic Unit Price Structure of Material in Construction Projects

\subsection{Systems Dynamic Approach}

The complexity and dynamics nature of construction project implementation are always related to prediction analysis since each project always different and changes in overtime and influencing to the process of project planning. So, the analysis of changes that are needed. One appropriate method is the system dynamics, especially related to the budget costs in projects.

The step to analysis using system dynamics approach is divided into several stages, namely [12]:

a. Identification and definition the problem

This stage contains the system boundaries so that identified the components of systems.

b. System conceptualization

By identifying the components of system and interaction of each components to others. Plotting the causatic diagram and then continue with filling the mathematical equation in stock flow diagram. This step is one of the keys in system dynamic analysis where is a causal loop in an integrated system.

c. Model Formulation

Based on the causatic diagram, the formulation is needed quantify the data so the result will be found. Ventana simulation or vensim is one of the software tools to help the analysis in system dynamics become so easy and fast.

d. Verification dan Validation Model

If the base model has already developed, then the verification and validation is done to ensure the accuracy of the model is closed to real condition.

e. Scenarios and Simulation Model

When the model is valid, it can be done the scenarios and simulation in system that have already developed based on the needs of users.

f. Policy Analysis

Policy analysis is the process of giving advice on the policy to be implemented based on the scenarios that has been done through the developed model. g. Implementation of Policy

Implementation of the model and evaluation for next development

The scope of the analysis includes the handling of project financing and building maintenance or improvement of the performance capacity of public works in particular on the analysis of material needs in the field of water resources. Based on the SNI Indonesian standard, the coefficients index of material needs of the stone masonry with the specification $1 \mathrm{Pc}$ : $3 \mathrm{~S}$ is Stone $\left(1.2 \mathrm{~m}^{3}\right)$, Portland cement (4.05 sack) and Sand $\left(0.486 \mathrm{~m}^{3}\right)$. This analysis will be used as example in this study.

According to the literatures review, the components identified early in the material financing system are:

a. Fluctuation on market price of material

b. Inflation Rate

c. Economic growth and rate of the economic growth

d. Taxes of construction material

e. Specification of construction material

f. Location and distance of material quarry

g. The Basic unit price of material

$\mathrm{h}$. The value of coefficient index of materials in SNI

i. The Unit price of work

j. Unit of Volume

k. Profit

1. General cost

\subsection{Analysis of Influencing Factors of Material Needs}

The components that affect to the unit price of construction material are as follows:

\section{Inflation}

Inflation is an indicator to see the rate of change, and it is assumed to happen if the changing process is continuous and mutually interrelationship. The rate of inflation used in this study is inflation occurring in the 2000- 2015 periods, as shown in Table 1 and Figure 3. 
Table 1 The Rate of Inflation

\begin{tabular}{cccc}
\hline \multirow{2}{*}{ Year } & \multicolumn{3}{c}{ Inflation $(\%)$} \\
\cline { 2 - 4 } & $\mathrm{x}$ & $\mathrm{x}-\mathrm{mean}$ & $(\mathrm{x}-\mathrm{mean})^{2}$ \\
\hline 2000 & 9.35 & 0.80 & 0.64 \\
\hline 2001 & 12.55 & 4.00 & 16.01 \\
\hline 2002 & 10.03 & 1.48 & 2.19 \\
\hline 2003 & 5.16 & $(3.39)$ & 11.49 \\
\hline 2004 & 6.40 & $(2.15)$ & 4.62 \\
\hline 2005 & 17.11 & 8.56 & 73.29 \\
\hline 2006 & 6.60 & $(1.95)$ & 3.80 \\
\hline 2007 & 6.59 & $(1.96)$ & 3.84 \\
\hline 2008 & 11.06 & 2.51 & 6.30 \\
\hline 2009 & 2.78 & $(5.77)$ & 33.29 \\
\hline 2010 & 6.96 & $(1.59)$ & 2.53 \\
\hline 2011 & 3.79 & $(4.76)$ & 22.65 \\
\hline 2012 & 4.30 & $(4.25)$ & 18.06 \\
\hline 2013 & 8.38 & 8.38 & 70.22 \\
\hline 2014 & 8.36 & 8.36 & 69.89 \\
\hline 2015 & 8.82 & 8.82 & 77.79 \\
\hline Mean & 8.55 & Varian & 29.76 \\
\hline & & DS & 5.45 \\
\hline
\end{tabular}

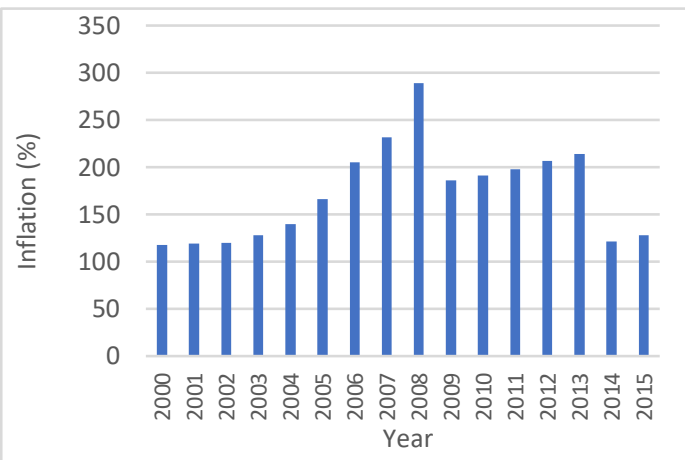

Figure 3 Graph of Inflation Rate Changes

2. Economic Growth

Generally, the economic growth will be influencing the rate of infrastructure development growth. Economic growth is also impressing the price of construction materials and equipment. As well as inflation rate, the economics growth is analysed in the period of 2000 - 2015, as shown in Figure 4 and Table 2 [13].

Table 2 Percentage Number of The Economic Growth in Indonesia

\begin{tabular}{cccc}
\hline \multirow{2}{*}{ Year } & \multicolumn{3}{c}{ Economic Growth $(\%)$} \\
\cline { 2 - 4 } & $\mathrm{x}$ & $\mathrm{x}-\mathrm{m}$-an & $(\mathrm{x}-\mathrm{mean})^{2}$ \\
\hline 2000 & 4.86 & $(0.85)$ & 0.72 \\
\hline
\end{tabular}

\begin{tabular}{cccc}
\hline 2001 & 3.45 & $(2.26)$ & 5.10 \\
\hline 2002 & 3.66 & $(2.05)$ & 4.20 \\
\hline 2003 & 4.10 & $(1.61)$ & 2.59 \\
\hline 2004 & 4.80 & $(0.91)$ & 0.83 \\
\hline 2005 & 5.60 & $(0.11)$ & 0.01 \\
\hline 2006 & 5.50 & $(0.21)$ & 0.04 \\
\hline 2007 & 6.30 & 0.59 & 0.35 \\
\hline 2008 & 7.00 & 1.29 & 1.67 \\
\hline 2009 & 4.57 & $(1.14)$ & 1.30 \\
\hline 2010 & 6.10 & 0.39 & 0.15 \\
\hline 2011 & 6.10 & 0.39 & 0.15 \\
\hline 2012 & 6.50 & 0.79 & 0.63 \\
\hline 2013 & 6.30 & 6.30 & 39.69 \\
\hline 2014 & 5.20 & 5.20 & 27.04 \\
\hline 2015 & 5.60 & 5.60 & 31.36 \\
\hline Mean & 5.71 & Varian & 8.27 \\
\hline & & DS & 2.88 \\
\hline
\end{tabular}

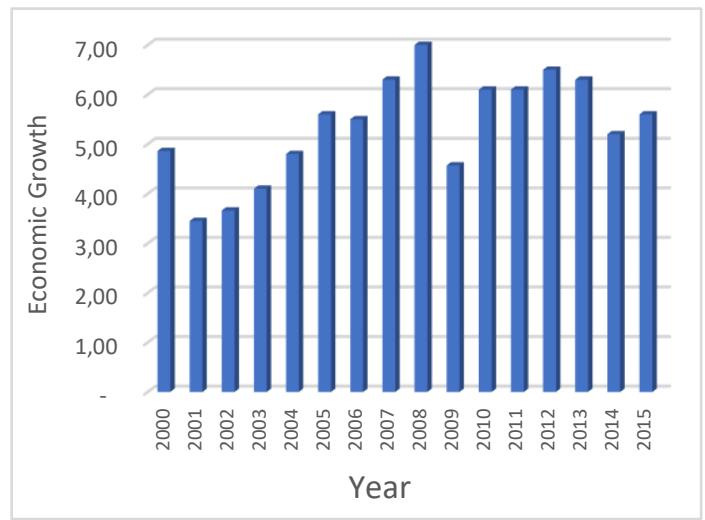

Figure 4 Number of Economic Growth in Indonesia

3. Income Per Capita of Populations Income per capita contributes to the salary of construction workers. This income per capita determines the level of prosperity of the populations, so that the living cost index will be determined the amount of the salary for construction workers, as shown in Figure 5 and Table 3 . 
Table 3 Income Per Capita of Population

\begin{tabular}{cccccc}
\hline \multirow{2}{*}{ Year } & \multicolumn{5}{c}{ Income Per Capita of Population (Rupiah) } \\
\cline { 2 - 6 } & Per year & Per day & $\begin{array}{c}\mathrm{x} \\
\text { \% level) }\end{array}$ & x-mean & $\begin{array}{c}(\mathrm{x}- \\
\text { mean) }\end{array}$ \\
\hline 2000 & 6171342.91 & 19907.56 & 0.54 & 2.80 & 7.84 \\
\hline 2001 & 6083368.92 & 19623.77 & 1.43 & 1.91 & 3.65 \\
\hline 2002 & 6185375.02 & 19952.82 & 1.65 & 1.69 & 2.86 \\
\hline 2003 & 6258043.21 & 20187.24 & 1.16 & 2.18 & 4.75 \\
\hline 2004 & 6605845.36 & 21309.18 & 5.27 & -1.93 & 3.72 \\
\hline 2005 & 6845163.54 & 22081.17 & 3.50 & -0.16 & 0.03 \\
\hline 2006 & 7034952.80 & 22693.40 & 2.70 & 0.64 & 0.41 \\
\hline 2007 & 7392111.69 & 23845.52 & 4.83 & -1.49 & 2.22 \\
\hline 2008 & 7927938.47 & 25574.00 & 6.76 & -3.42 & 11.70 \\
\hline 2009 & 7994083.18 & 25787.37 & 0.83 & 2.51 & 6.30 \\
\hline 2010 & 8488596.72 & 27382.57 & 5.83 & -2.49 & 6.20 \\
\hline 2011 & 9027335.72 & 29120.44 & 5.97 & -2.63 & 6.92 \\
\hline 2012 & 9665117.07 & 31177.80 & 6.60 & -3.26 & 10.63 \\
\hline 2013 & 9798899.43 & 31609.35 & 1.37 & 1.97 & 3.88 \\
\hline 2014 & 9834523.42 & 31724.27 & 0.36 & 2.98 & 8.88 \\
\hline 2015 & 9970416.19 & 32162.63 & 1.36 & 1.98 & 3.92 \\
\hline \multicolumn{7}{c}{} & & Mean & 3.34 & Varian & 5.99 \\
\hline
\end{tabular}

Figure 5 Number of Income Per Capita (Rupiah)

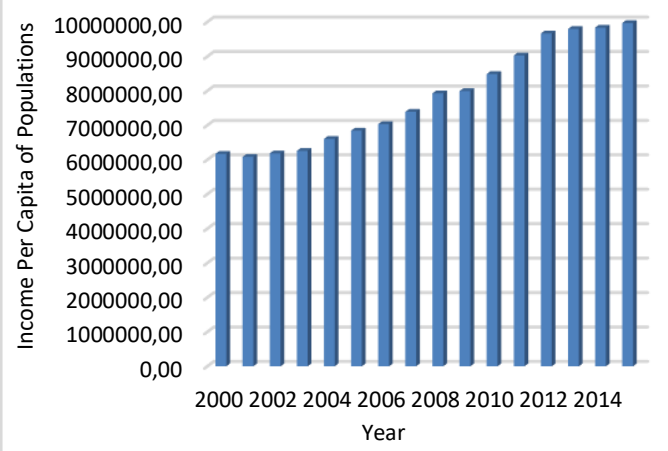

4. The Price Index of Basic Needs

The price index of basic needs affects the growth of people consumption so it will be influencing the living cost index. Together with the prosperity index, so the price index of basic needs will influence the rate of material needs, as shown in Figure 6 and Table 4.

Table 4 Number of Price Index of Basic Needs

\begin{tabular}{ccccc}
\hline \multirow{2}{*}{ Year } & \multicolumn{4}{c}{ Price Index of Basic Needs } \\
\cline { 2 - 5 } & Value & $\mathrm{x}$ & $\mathrm{x}-\mathrm{mean}$ & $(\mathrm{x}-\mathrm{mean})^{2}$ \\
\hline 2000 & 118 & 3.39 & 8.89 & 79.03 \\
\hline 2001 & 119 & 0.84 & 11.44 & 130.10 \\
\hline 2002 & 120 & 0.83 & 11.45 & 131.10 \\
\hline 2003 & 128 & 6.25 & 6.03 & 36.36 \\
\hline 2004 & 140 & 8.57 & 3.71 & 13.76 \\
\hline 2005 & 166 & 15.66 & -3.38 & 11.42 \\
\hline 2006 & 205 & 19.02 & -6.74 & 45.43 \\
\hline
\end{tabular}

\begin{tabular}{ccccc}
\hline 2007 & 232 & 11.64 & 0.64 & 0.41 \\
\hline 2008 & 289 & 19.72 & -7.44 & 55.35 \\
\hline 2009 & 186 & 35.64 & -23.36 & 545.69 \\
\hline 2010 & 191 & 2.62 & 9.66 & 93.32 \\
\hline 2011 & 198 & 3.54 & 8.74 & 76.39 \\
\hline 2012 & 207 & 4.35 & 7.93 & 62.88 \\
\hline 2013 & 214 & 3.27 & 9.01 & 81.18 \\
\hline 2014 & 121 & 43.46 & -31.18 & 972.19 \\
\hline 2015 & 128 & 5.47 & 6.81 & 46.38 \\
\hline & Mean & 12.28 & Varian & 170.13 \\
\hline & & & DS & 13.04 \\
\hline
\end{tabular}

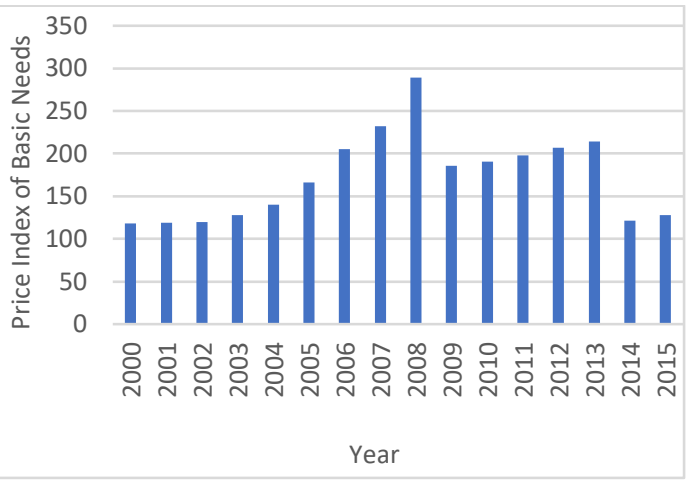

Figure 6 Price Index of Basic Needs

5. The Price of Building Materials

One of the factors affecting project financing is the price of building materials. Building materials have an important role in project financing because it will directly affect the success of project completion. The number of material rate, especially for Portland cement as shown in Figure 7.

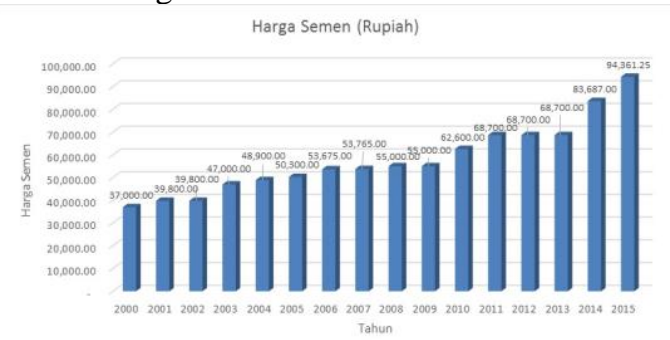

Figure 7 The Graph of Price Change of Portland Cement Building Material

Fluctuations in the price of building materials have a large contribution in project financing. One of the examples of the price of materials used in this study is the price of Portland cement in which almost all type of building must use this material especially in masonry. 


\subsection{Causatic Diagram}

In accordance to the results of components identification for system, it can be used as input to determine the interaction between components of the developed system. The interaction results between the components are arranged in a causatic diagram. The causation diagram of the project cost is constructed using the vensim software tool for easy and efficient operation as shown in Figure 8 [14].

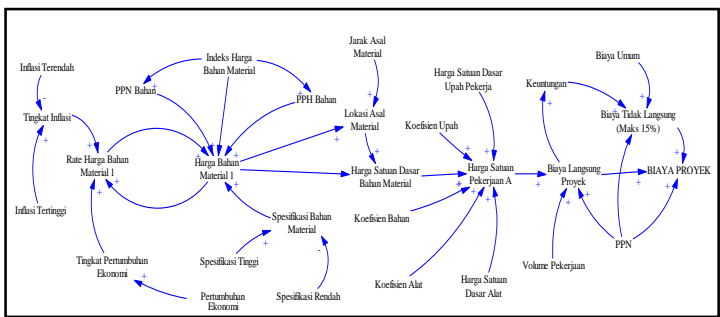

Figure 8 Causatic Diagram of Material Project Cost

The project cost system is affected by the direct and indirect costs incurred in planning a construction project as an accumulation from multiplication between the unit price of work with the volume of work on each sub work, carried out and with the taxes, profits and general costs to be prepared for project implementation. The larger and complex volume of work to be completed, the amount of direct costs is also greater, so there is a positive relationship between the unit price of work, volume of work and direct costs.

The direct costs depend on the unit price of work from the detail breakdown structures of activities in project. The unit price of work is influenced by the volume of work that has been identified. The unit price of work is related with the basic unit price of salary and material needs, but for this study, we focus on construction materials. Besides the basic unit price, it needs the coefficients index based on national standard Indonesia (SNI). The coefficient value shows the productivity generated by each activity in accordance with the breakdown structures. The unit price of the material is influenced by the location and distance of the material due to the transportation cost. Likewise, the material specification used will also determine the price of the material. Other components that influence the price of materials are the inflation rate and the general rate of economic growth that occurs. Indirect cost is allocated a maximum of $15 \%$ of the total project cost. These indirect costs also accommodate risk factors due to the complexity of the work to be carried out.

\subsection{Stock Flow Diagram for The Project Cost}

In Causatic diagram, it can be described the interrelationship between the components supporting the system, but con not be done assessment on each component if there are changes to the developed system. To show the value of changes in the system, so given the mathematical equations on the relationship between the components in stock flow diagram. The relationship between components in formulation of stock flow diagram as in figure 9 and the result of running model shown in figure 10 [14].

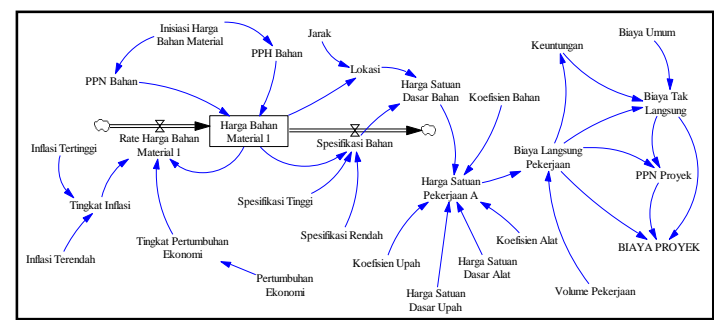

Figure 9 Stock Flow Diagram

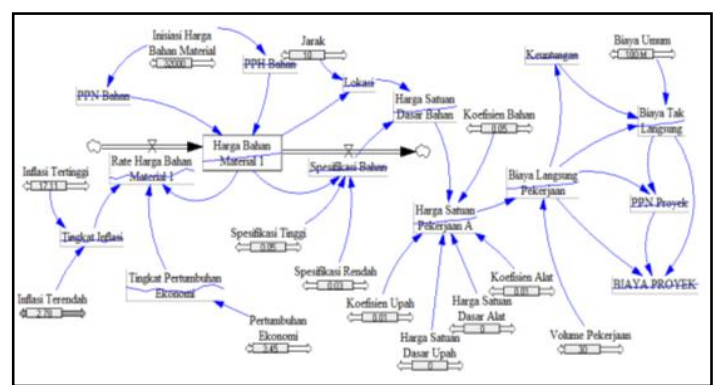

Figure 10 The Result of Running Model

According to the running model, its shown that the model has been verified, because there is no error when the program was executed. So, we can continue the step with display the result of the model. for example, here is the prediction of material price and the total cost for ten years, as shown in Figure 11 and Figure 12 [15]. 


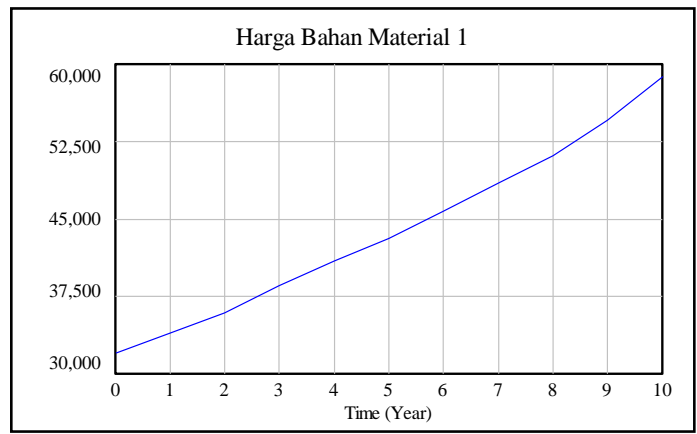

Figure 11 The Prediction Number of Material Price

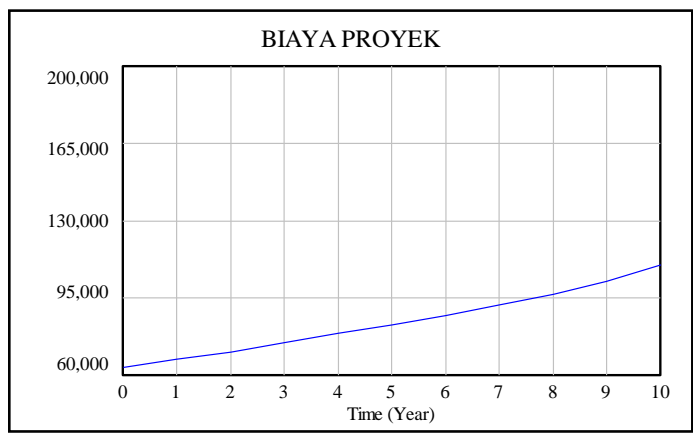

Figure 12 The Prediction Number of The Total Project Cost

\subsection{Model Validation}

The verification of the model showed that there was no error in the model execution, so the results could be displaying the prediction value. After the results obtained from the running model, that can be made validation stage to ensure that the model is arranged in accordance with the whites, expectations and real conditions that are modelled.

The Validation of simulation model is eligible based on the value of means comparison, $\mathrm{E}_{1}=$ $0.32 \%<5 \%$ and $\%$ error variance, $\mathrm{E}_{2}=3.19 \%<$ $30 \%$ so the developed model was closes to the real condition to real conditions. Furthermore, it can be done the scenarios through the model in accordance with the needs of users in the case related to the project's cost including predicting material needs in the future.

\section{Conclusions}

The results of approach model using system dynamic can be used by the parties concerned with the budget to make predictions number and project costs estimation for the future. The policy changes can be poured on the scenarios in the model compiled as one of the advantages of system dynamics.
The verification of the model showed that there was no error in the model execution using vensim tools. While the validation of the model has a good accuracy and closed to the real conditions based on the value of means comparison, $\mathrm{E}_{1}=0.32 \%<5 \%$ and $\%$ error variance, $\mathrm{E}_{2}=3.19 \%<30 \%$ it can be done the scenarios through the model in accordance with the needs of users in the case related to the project's cost including predicting material needs in the future.

\section{References}

[1] Akintoye, A. (2000). Analysis of Factors Influencing Project Cost Estimating Practice. Construction Management and Economic, 77 - 89.

[2] Toh, Tien-Choon; Ting, Connie; Ali, Kherun-Nita; Aliagha, Godwin-Uche, 2012, Critical Cost Factors of Building Constructions Projects in Malaysia, International Conference on Asia Pasific Bussinness Innovation and Technology Management, Procedia-Social and Behavioural Sciences 57, 360 - 367, 2012

[3] Betlejewska, R. S., \& Potkany, M. (2015). Construction Costs Analysis And Its Importance To The Economy. Business Economics and Management 2015 Conference, BEM 2015, (pp. 35 - 42).

[4] Cheng, Y. M. (2014). An Exploration Into Cost Influencing Factors On Construction Projects. International Journal of Project Management, 850-860

[5] Winanda, Lila Ayu Ratna 2010, Penggunaan Neural Network Metode Back Propagation Untuk Estimasi Produktivitas Pekerja Konstruksi, Prosiding Seminar Nasional Teknik Sipil VI, ITS Surabaya

[6] Cheng, M. Y., Tsai, H. C., \& Sudjono, E. (2010). Conceptual Cost Estimates Using Evolutionary Fuzzy Hybrid Neural Network for Projects in Construction Industry. Expert System with Applications, 4224-4231.

[7] Winanda, Lila Ayu Ratna; Hirijanto; Munasih, 2015, Model Aplikasi Sistem Informasi Analisa Harga Satuan Pekerjaan Konstruksi, Prosiding Seminar Nasional FTSP ITN Malang, 2015

[8] Cheng, M. Y., Tsai, H. C., \& Hsieh, W. S. (2009). Web Based Conceptual Cost Estimates for Construction Projects Using Evolutionary Fuzzy Neural Inference Model. Automation in Construction, 164172. 
[9] Idrus, A., Nurudin, M. F., \& Rohman, M. A. (2011). Development of Project Cost Contigency Estimation Model Using Risk Analysis and Fuzzy Expert System. Expert System with Application, 1501-1508.

[10] Hirijanto; Hidayat, Sutanto, 2016, Sistem Dinamis Untuk Memprediksi Harga Satuan Bahan Material Pekerjaan Sumber Daya Air, Konferensi Nasional Teknik Sipil X, Universitas Atmajaya, Yogyakarta

[11] Balitbang Pekerjaan Umum, 2012, Pedoman Bahan Konstruksi bangunan dan Rekayasa Sipil, Kementriam Pekerjaan Umum

[12] Utami, Rahayu, 2006, Simulasi Dinamika Sistem Ketersediaan Ubi kayu, Skripsi, Institut Pertanian Bogor

[13] Badan Pusat Statistik, www. bps.go.id

[14] Suryani Erma, 2011, Sistem Profit Perbankan BUMN Indonesia (Sudi Kasus:Bank Mandiri 2006), JUTI Volume 9, Nomor 2.

[15] Dinas Pengairan Kabupaten Malang, 2015, Database daftar harga bahan dan material 